\title{
Depth-dependent geometry of margin-parallel strike-slip faults within oblique subduction zones
}

\author{
*Nicole Catalán ${ }^{1}$, Klaus Bataille ${ }^{1}$, Andrés Tassara ${ }^{1}$, Rodolfo Araya ${ }^{2}$ \\ 1 Departamento Ciencias de la Tierra, Facultad de Ciencias Químicas, Universidad de Concepción, Víctor Lamas 1290, Concepción, Chile. \\ nicolecatalan@udec.cl; bataille@udec.cl; andrestassara@udec.cl \\ 2 Departamento de Ingeniería Matemática and CI2MA, Universidad de Concepción, Víctor Lamas 1290, Concepción, Chile. \\ rodaraya@udec.cl \\ *Corresponding author: nicolecatalan@udec.cl
}

\begin{abstract}
Based on the principle that faults develop where shear stress is maximum, we determine the depth-dependent geometry of margin-parallel strike-slip faults within oblique subduction zones. Using an elastic half-space model for the south Chile subduction zone, we show that the geometry of a margin-parallel strike-slip fault as the Liquiñe-Ofqui Fault Zone (LOFZ), is vertical near the free surface and curved downwards, until reaching the subducting slab. This geometry is compatible with the observations of reflectors on seismic data obtained from wide angle refraction studies in southern Chile. GPS measurements also support this curved geometry. We suggest that this curved pattern should occur on all margin-parallel strike-slip faults within oblique subduction zones worldwide.
\end{abstract}

Keywords: Oblique subduction, Margin-parallel strike-slip faults, Southern Andes, Liquiñe-Ofqui Fault Zone.

RESUMEN. Geometría en profundidad de fallas de rumbo paralelas al margen en zonas de subducción oblicua. Basados en el principio de que las fallas se desarrollan donde el esfuerzo de cizalle es máximo, determinamos la geometría en profundidad de fallas de rumbo paralelas al margen en zonas de subducción oblicua. Usando un modelo de semiespacio elástico para la zona de subducción del sur de Chile, mostramos que la geometría de una falla de rumbo paralela al margen como la Zona de Falla Liquiñe-Ofqui (LOFZ), es vertical cerca de la superficie libre y cóncava hacia abajo, hasta alcanzar la placa subductada. Esta geometría es compatible con las observaciones de reflectores obtenidos a partir de estudios de refracción sísmica en el sur de Chile. Mediciones GPS también soportan esta geometría curva. Sugerimos que esta geometría debería ocurrir en todas las fallas de rumbo paralelas al margen en zonas de subducción oblicua alrededor del mundo. 


\section{Introduction}

In oblique subduction zones, margin-parallel strike-slip faults accommodate part of the trenchparallel component of convergence. The presence of this type of faults, together with factors such as the obliquity angle (angle between the convergence vector and the normal to the plate boundary), the age of the subducting plate, the nature of the overriding plate and ridge subduction would control the degree of convergence partition (Fitch, 1972; Jarrard, 1986; Beck, 1991; McCaffrey, 1992, 1996; Nelson et al., 1994; Tikoff and Teyssier, 1994). The location of margin-parallel strike-slip faults has been attributed to weakening in the crust, due to the high temperatures associated with magmatism (Beck, 1983; Tikoff,
1998), however, only some of these faults coincide with volcanic arcs worldwide. Using a model of oblique convergence based on the finite element method to the area of Sumatra, McCaffrey et al. (2000) suggest that the location of a margin-parallel strike-slip fault in the overriding plate is controlled by the stress distribution at the downdip end of interplate coupling across the megathrust.

In the southern Andes, the Nazca plate is subducted beneath South American plate with a convergence rate of $\sim 66 \mathrm{~mm} / \mathrm{yr}$ and an obliquity angle of $18^{\circ}$ (Angermann et al., 1999). The Liquiñe-Ofqui Fault Zone (LOFZ) runs parallel to the Nazca-South America plate boundary between $\sim 38^{\circ}-48^{\circ} \mathrm{S}$, aligned with the active Southern Volcanic Zone (Fig. 1). The LOFZ has been active as a transpressional dextral

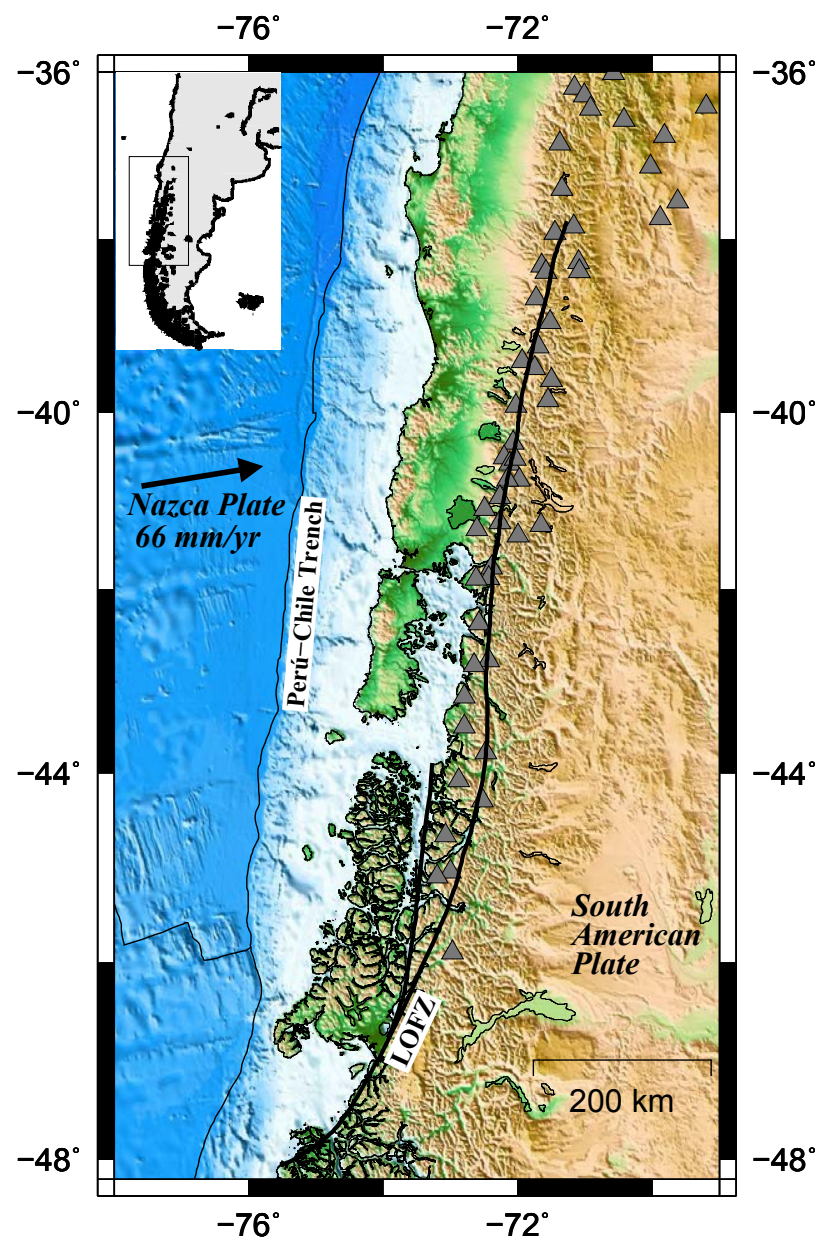

FIG. 1. Tectonic setting of the southern Chile. The location of the Liquiñe-Ofqui Fault Zone (LOFZ) is shown (modified from Cembrano and Lara, 2009). Gray triangles indicate volcanoes of the Southern Volcanic Zone. 
strike-slip structure at least over the last $6 \mathrm{Ma}$ (Hervé, 1994; Cembrano et al., 1996; Arancibia et al., 1999; Lavenu and Cembrano, 1999; Cembrano et al., 2002; Thomson, 2002; Adriasola et al., 2006; Rosenau et al., 2006). Seismic and geodetic data have shown the active nature of the LOFZ (Lange et al., 2007, 2008; Wang et al., 2007).

Currently, the depth-dependent geometry of the LOFZ and other margin-parallel strike-slip faults that occur in different margins of oblique convergence worldwide, is still unknown. This paper seeks to clarify this topic, analyzing the three-dimensional distribution of shear stress inside the overriding plate obtained from an elastic half-space model of oblique subduction.

\section{Methodology}

Static shear stress within the crust depends on the loading source and the elastic parameters of the crust. The loading source is modeled here by a set of dislocations that represent the oblique subduction of a slab. The geometry of dislocations follows the geometry of subduction, but here we simplify it by having a constant dip angle. The upper portion of the subduction interface remains locked. This geometry follows the basic idea of Sieh et al. (1999) and Kanda and Simons (2010), as shown in figure 2. Using the analytical expressions of Okada (1992) for an elastic, homogeneous, isotropic, and Poisson-solid half-space, the deformation produced by dislocations was calculated.

We are interested in finding for any point on the overriding plate, the plane at which the marginparallel shear stress is maximum, which is given by:

$\tau \mathrm{xn}=\tau \mathrm{xy} n \mathrm{y}+\tau \mathrm{xz} n \mathrm{z}=\tau \mathrm{xy} \sin (\theta)+\tau \mathrm{xz} \cos (\theta)$ where $x$ and $y$ are the directions parallel and normal to the plate boundary, respectively, and $z$ is depth, $n$ is the normal vector to the plane of maximum margin-parallel shear stress at a given point, and $\theta$ is the angle between the surface and that plane (Fig. 2). The orientation of the plane is given by the angle $\theta$ that maximizes the value of $|\tau \times n(\theta)|$, for $\theta=\left(0: 180^{\circ}\right)$.

\section{Results}

The family of planes of maximum margin-parallel shear stress obtained by modeling the oblique subduction of the Nazca plate beneath South America in southern Chile, is shown in figure 3 . The model considers an oceanic plate of $20 \mathrm{~km}$ thick, dip angle of $15^{\circ}$, and depth to the downdip end of interplate coupling of $50 \mathrm{~km}$. A convergence rate of $66 \mathrm{~mm} / \mathrm{yr}$ and an obliquity angle of $18^{\circ}$ were used (Angermann et al., 1999).

Considering a normal distance between the trace of the LOFZ and the Peru-Chile trench of $270 \mathrm{~km}$ (Fig. 1), we calculate the geometry of the LOFZ from the planes of maximum margin-parallel shear stress. The resulting LOFZ is vertical near the free surface and smoothly curved with increasing depth, until reaching the subducting slab (Fig. 4a). This geometry is compatible with the reflector at the eastern end of the seismic reflection profile at $38.2^{\circ} \mathrm{S}$, shown in figure $4 b$ (Gross et al., 2007).

Relative motion along the resulting LOFZ should produce margin-parallel velocity on the surface, which can be compared with GPS measurements. We calculate the margin-parallel velocity on the surface, due to both: (a) oblique motion of the subducting oceanic slab, and (b) strike-slip motion on the resulting LOFZ. For these two sources, margin-parallel velocity on

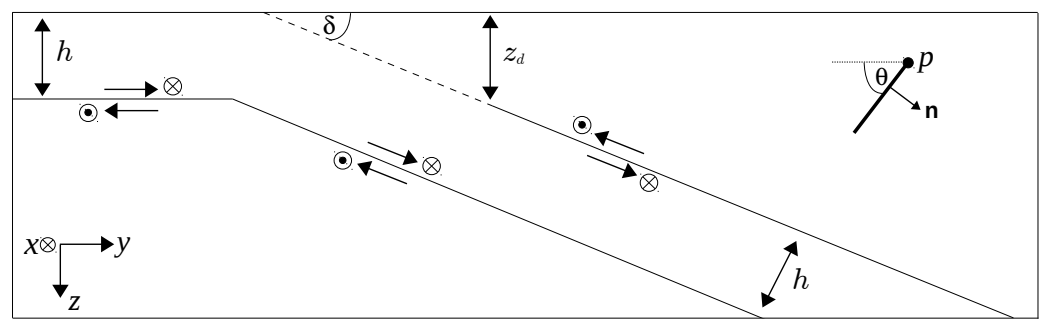

FIG. 2. Cross section of geometry of oblique subduction for a homogeneous elastic media, with dislocations surrounding the brittle oceanic plate. $x$ and $y$ are the directions parallel and normal to the margin, respectively; $z$ is depth; $h$ is the plate thickness; $\delta$ is the dip angle of subduction; $z \mathrm{~d}$ is the depth to the downdip end of interplate coupling. At any point $p, \theta$ is the angle between the surface and the plane (normal to vector $n$ ) at which margin-parallel shear stress ( $\tau \times n)$ is maximum. 


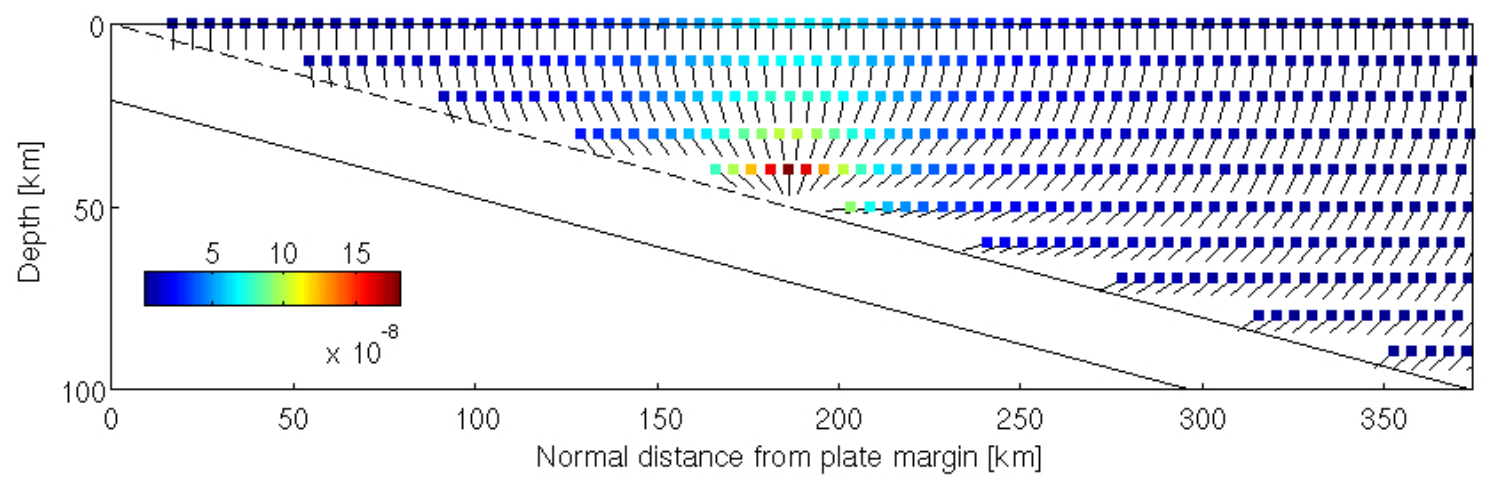

FIG. 3. Family of planes with maximum margin-parallel shear stress across the crust obtained for the south Chile subduction zone. Higher shear stress values are near the downdip depth. The effect of temperature on friction, favors a more inclined plane. The color bar displays the magnitude of shear strain.
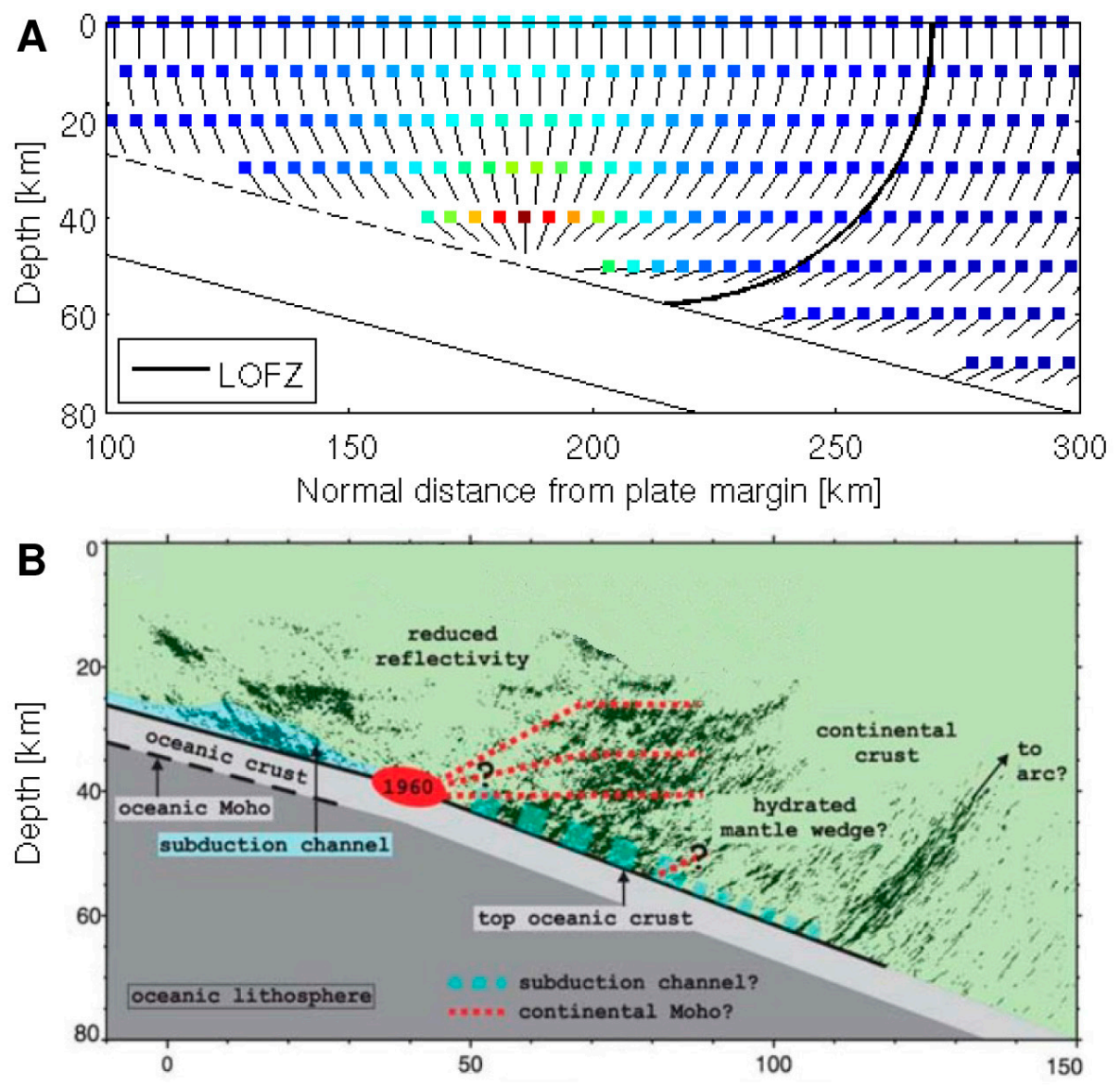

Normal distance from coast [km]

FIG. 4. A. Proposed geometry for the LOFZ. It is vertical near the free surface, and curved downwards, suggesting possible paths of fluids from the downgoing slab towards the volcanic arc. The planes of maximum margin-parallel shear stress are shown as in figure 3; B. Seismic reflection profile at $38.2^{\circ} \mathrm{S}$ (modified from Gross et al., 2007). We note the coincidence of the easternmost reflector of the profile and the proposed geometry for the LOFZ. 
the surface were modeled and compared with GPS measurements for southern Chile, between $37^{\circ}-40^{\circ} \mathrm{S}$ (Klotz et al., 2001; Ruegg et al., 2009; Moreno et al., 2011). Our model assumes that the LOFZ accommodates half of the strike-slip component of the relative motion between the Nazca and South America plates, and the fault remains locked up to $20 \mathrm{~km}$ depth (Fig. 5a).
In figure 5b, horizontal GPS velocities projected parallel to the margin, and margin-parallel velocities predicted by the model are plotted as a function of the normal distance from plate margin. It is noted that the GPS velocities are successfully reproduced by the model. A comparison between the observed and modeled velocity vectors, and corresponding residuals, are shown in figures $5 \mathrm{c}$ y $5 \mathrm{~d}$, respectively.
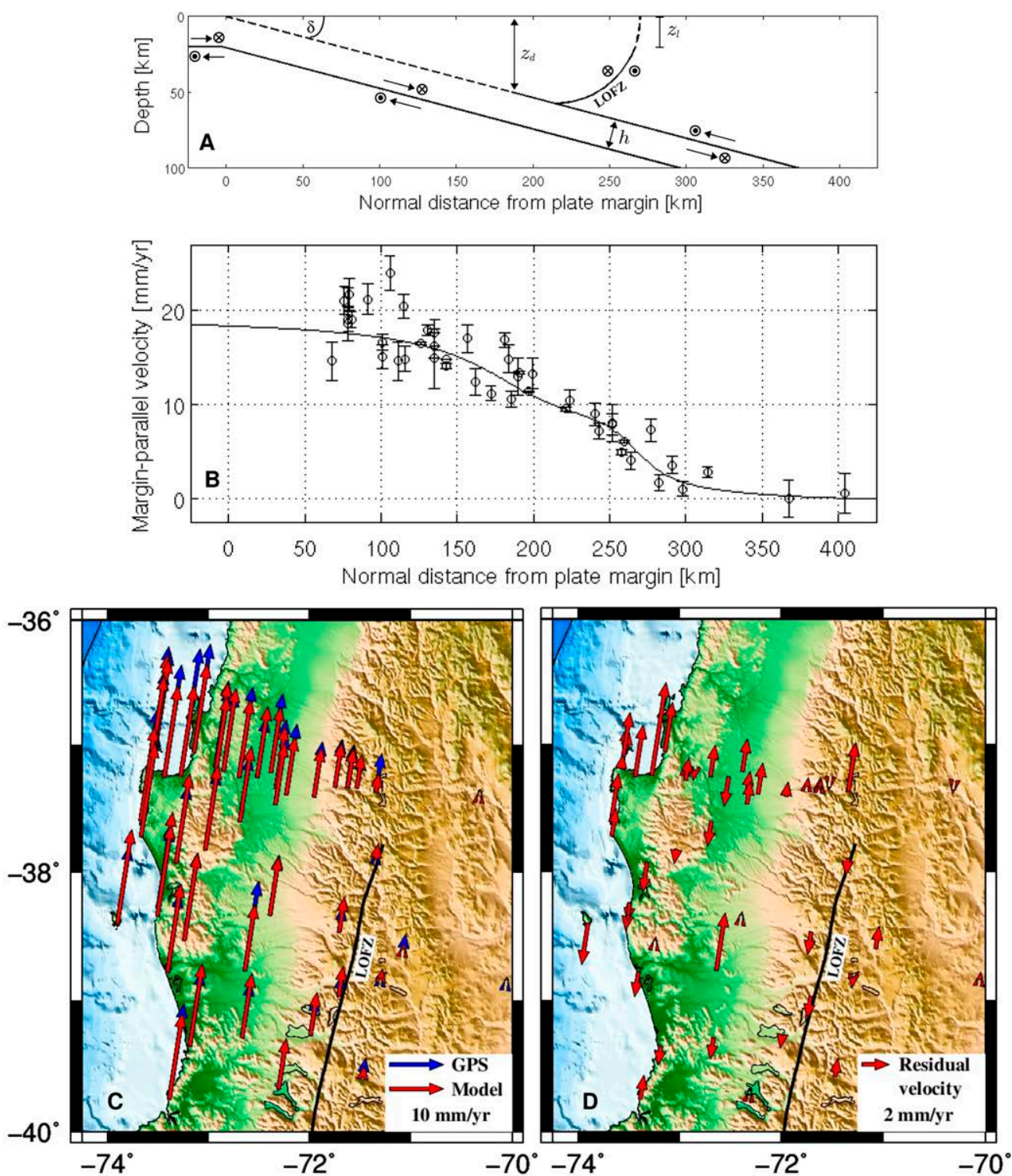

FIG. 5. A. Geometry of the best-fit model. This model considers both oblique motion of the subducting slab and strike-slip motion along the resulting LOFZ. $z$ is the locking depth for the LOFZ. Other notations are same as figure 2. The LOFZ accommodates half of the margin-parallel component of plate convergence. Observed versus modeled margin-parallel velocities between $37^{\circ}$ $40^{\circ} \mathrm{S}$, in B cross section, and C map view. D. Residual velocities obtained by subtracting the model from the GPS velocities. 
The effects that variations in model parameters have on the margin-parallel velocities on the surface, and root-mean-square (RMS) response, are shown in figure 6. Among the parameters involved in our calculations, are (a) the depth to the downdip end of interplate coupling, (b) the dip angle of subduction, and (c) the percentage of the margin-parallel component of oblique convergence accommodated by the LOFZ. In figure $6 \mathrm{a}$, we can see that the margin-parallel velocity decreases as the downdip depth decreases. The main effect of the dip angle is to shift the curve towards the trench as the dip angle increases (Fig. 6b). Variations in the strike-slip rate and locking depth of the LOFZ, have similar effects on the calculated margin-parallel velocities. Considering a locking depth of $20 \mathrm{~km}$, the percentage of the margin-parallel component of oblique convergence accommodated by the LOFZ varied between $0-100 \%$ (Fig. 6c). Changes in the slab thickness have little effect on the results. Our preferred model, with an oceanic plate of $20 \mathrm{~km}$ thick, dip angle of $15^{\circ}$, depth to the downdip end of interplate coupling of $50 \mathrm{~km}$, and the LOFZ accommodating half of the strike-slip component of oblique convergence, provides the lowest RMS of $2.22 \mathrm{~mm} / \mathrm{yr}$ (Fig. 6).

\section{Discussion}

Currently, the depth-dependent geometry of marginparallel strike-slip faults within oblique subduction zones, is still unknown. Based on a model of oblique convergence for southern Chile, we propose that the LOFZ, a transpressional dextral strike-slip structure parallel to the Nazca-South America plate boundary, has a curved geometry in depth, as shown in figure 4a. We note that this geometry is in agreement with the easternmost reflector of the seismic reflection profile obtained by Gross et al. (2007), from wide angle refraction studies at $38.2^{\circ} \mathrm{S}$ (Fig. 4b). Although the nature and origin of this reflector is still unclear, the authors noted the spatial coincidence of the extrapolation to the surface of this reflector and the trace of the LOFZ. The other areas of high reflectivity observed in the profile, would be consistent with the geometry of the planes of maximum shear stress obtained by our model: East- and west-dipping planes to the left and right of the downdip depth limit, respectively (Fig. 4).

As both plates collide, the value of shear stress at each plane increases at the same rate as the convergence rate. As shear stress increases and the plane breaks, friction coefficient is reduced on such plane and it is likely to be the place of future rupture. Which of all planes initially breaks depends on several factors, including the temperature profile, its particular composition and past history of deformation. Considering the earthquake cycle, with complementary coseismic and interseismic periods both having maximum shear stresses near the downdip depth, it is likely that the planes reaching close to this downdip zone are best candidates to develop as long term faults. The effect of temperature on friction, would promote the development of faults along planes distant to this downdip zone.

\section{Conclusion}

Here we show that for any oblique subduction zone, the depth-dependent geometry of a potential

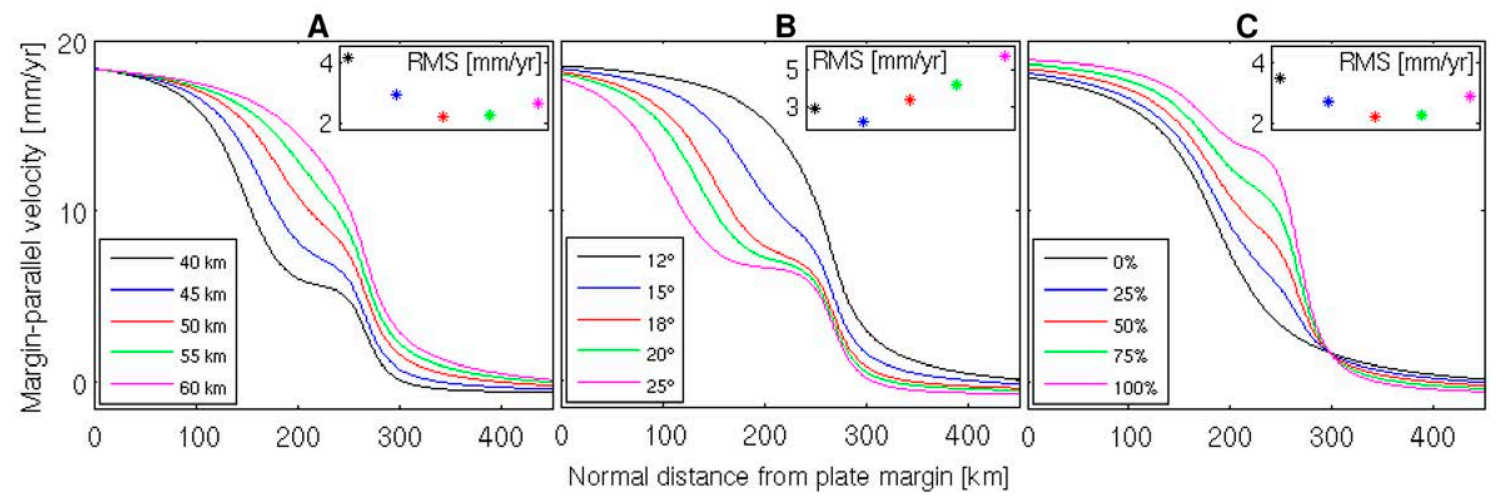

FIG. 6. Margin-parallel velocities and RMS, obtained for different values of: A. downdip depth limits; B. dip angles; and C. percentages of margin-parallel component of oblique convergence accommodated by the LOFZ. 
margin-parallel strike-slip fault, is vertical near the free surface and smoothly curved with increasing depth, until reaching the subducting slab. This geometry is consistent with observations of reflectors for southern Chile, in relation to the LOFZ (Gross et al., 2007).

In addition, we model the crustal deformation due to the combined effect of oblique motion of the Nazca plate plus strike-slip motion along the LOFZ, and compare with GPS observations in southern Chile. The parameters of both oblique subduction and strike-slip fault are determined by minimizing the difference between model results and observations. Along the subduction interface, we assume a plate velocity of $66 \mathrm{~mm} / \mathrm{yr}$ and an obliquity angle of $18^{\circ}$. The preferred model considers an oceanic plate of $20 \mathrm{~km}$ thick, dip angle of $15^{\circ}$ and depth to the downdip end of interplate coupling of $50 \mathrm{~km}$. The LOFZ remains locked up to $20 \mathrm{~km}$ depth, and accommodates half of the strike-slip component of oblique convergence.

\section{Acknowledgments}

This research was supported by FONDECYT projects 1100990, 1101034 and 1151175, and ECOS-CONICYT project $\mathrm{C} 13 \mathrm{U} 03$. NC acknowledges discussions with Dr. J. Quezada and financial support from CONICYT grant (CONICYT-PCHA/Doctorado Nacional/201521151394). RA was partially founded by CONICYT/ Chile through FONDECYT project No. 1150174, Basal project CMM-CI2MA PFB-03, Anillo project ACT1118 (ANANUM); and Red Doctoral REDOC.CTA, MINEDUC project UCO1202 at Universidad de Concepción. The data used are presented in the cited references. The authors are grateful for the constructive suggestions made by Dr. A. Folguera and Editor Dr. W. Vivallo.

\section{References}

Adriasola, A.C.; Thomson, S.N.; Brix, M.R.; Hervé, F.; Stockhert, B. 2006. Postmagmatic cooling and Late Cenozoic denudation of the North Patagonian Batholith in the Los Lagos Region of Chile, $41^{\circ} \mathrm{S}-42^{\circ} \mathrm{S}$. International Journal of Earth Sciences 95: 504-528.

Angermann, D.; Klotz, J.; Reigber, C. 1999. Space-geodetic estimation of the Nazca-South America Euler vector. Earth and Planetary Science Letters 171 (3): 329-334.

Arancibia, G.; Cembrano, J.; Lavenu, A. 1999. Transpresión dextral y partición de la deformación en la Zona de Falla Liquiñe-Ofqui, Aisén, Chile (44-45으). Revista
Geológica de Chile 26 (1): 3-21. doi: 10.5027/andgeo V26n1-a01

Beck Jr., M.E. 1983. On the mechanism of tectonic transport in zones of oblique subduction. Tectonophysics 93 (1-2): 1-11.

Beck Jr., M.E. 1991. Coastwise transport reconsidered: Lateral displacements in oblique subduction zones, and tectonic consequences. Physics of the Earth and Planetary Interiors 68 (1-2): 1-8.

Cembrano, J.; Lara, L. 2009. The link between volcanism and tectonics in the southern volcanic zone of the Chilean Andes: A review. Tectonophysics 471: 96-113.

Cembrano, J.; Hervé, F.; Lavenu, A. 1996. The Liquiñe Ofqui Fault Zone: A long-lived intra-arc fault system in southern Chile. Tectonophysics 259: 55-66.

Cembrano, J.; Lavenu, A.; Reynolds, P.; Arancibia, G.; López, G.; Sanhueza, A. 2002. Late Cenozoic transpressional ductile deformation north of the Nazca-South America-Antarctica triple junction. Tectonophysics 354: 289-314.

Fitch, T.J. 1972. Plate convergence, transcurrent faults, and internal deformation adjacent to southeast Asia and the western Pacific. Journal of Geophysical Research 77 (23): 4432-4460. doi: 10.1029/JB077i023p04432.

Gross, K.; Micksch, U.; TIPTEQ Research Group, Seismics Team. 2007. The reflection seismic survey of project TIPTEQ-the inventory of the Chilean subduction zone at $38.2^{\circ} \mathrm{S}$. Geophysical Journal International $172(2)$ : 565-571. doi:10.1111/j.1365-246X.2007.03680.x.

Hervé, F. 1994. The Southern Andes between $39^{\circ}$ and $44^{\circ} \mathrm{S}$ latitude: The geological signature of a transpressive tectonic regime related to magmatic arc. In Tectonics of the Southern Central Andes (Reutter, K.J.; Scheuber, E.; Wigger, P.J.; editors). Springer Verlag: 243-248.

Jarrard, R.D. 1986. Relations among subduction parameters. Reviews of Geophysics 24 (2): 217-284.

Kanda, R.; Simons, M. 2010. An elastic plate model for interseismic deformation in subduction zones. Journal of Geophysical Research 115: B03405. doi: 10.1029/2009JB006611.

Klotz, J.; Khazaradze, G.; Angermann, D.; Reigber, C.; Perdomo, R.; Cifuentes, O. 2001. Earthquake cycle dominates contemporary crustal deformation in central and southern Andes. Earth and Planetary Science Letters 193: 437-446. doi:10.1016/S0012821X(01)00532-5.

Lange, D.; Rietbrock, A.; Haberland, C.; Bataille, K.; Dahm, T.; Tilmann, F.; Fluh, E.R. 2007. Seismicity and geometry of the south Chilean subduction zone $\left(41.5^{\circ} \mathrm{S}-43.5^{\circ} \mathrm{S}\right)$ : Implications for controlling 
parameters. Geophysical Research Letters 34: L06311. doi: 10.1029/2006GL029190.

Lange, D.; Cembrano, J.; Rietbrock, A.; Haberland, C.; Dahm, T.; Bataille, K. 2008. First seismic record for intra-arc strike-slip tectonics along the Liquiñe-Ofqui fault zone at the obliquely convergent plate margin of the southern Andes. Tectonophysics 455: 14-24.

Lavenu, A.; Cembrano, J. 1999. Compressional and transpressional stress pattern for Pliocene and Quaternary brittle deformation in fore arc and intra-arc zones (Andes of Central and Southern Chile). Journal of Structural Geology 21: 1669-1691.

McCaffrey, R. 1992. Oblique plate convergence, slip vectors, and forearc deformation. Journal of Geophysical Research 97: 8905-8915.

McCaffrey, R. 1996. Estimates of modern arc-parallel strain rates in fore arcs. Geology 24 (1): 27-30.

McCaffrey, R.; Zwick, P.; Bock, Y.; Prawirodirdjo, L.; Genrich, J.; Stevens, C.W.; Puntodewo, S.S.O.; Subarya, C. 2000. Strain partitioning during oblique plate convergence in northern Sumatra: Geodetic and seismologic constraints and numerical modeling. Journal of Geophysical Research 105: 28363-28376.

Moreno, M.; Melnick, D.; Rosenau, M.; Bolte, J.; Klotz, J.; Echtler, H.; Baez, J.; Bataille, K.; Chen, J.; Bevis, M.; Hase, H.; Oncken, O. 2011. Heterogeneous plate locking in the South-Central Chile subduction zone: Building up the next great earthquake. Earth and Planetary Science Letters 305 (3-4): 413-424. doi: 10.1016/j.eps1.2011.03.025.

Nelson, E.; Forsythe, R.; Arit, I. 1994. Ridge collision tectonics in terrane development. Journal of South American Earth Sciences 7 (3-4): 271-278.

Okada, Y. 1992. Internal deformation due to shear and tensile faults in a half-space. Bulletin of the Seismological Society of America 82 (2): 1018-1040.
Rosenau, M.; Melnick, D.; Echtler, H. 2006. Kinematic constraints on intra-arc shear and strain partitioning in the Southern Andes between $38^{\circ} \mathrm{S}$ and $42^{\circ} \mathrm{S}$ latitude. Tectonics 25: TC4013. doi: 1029/2005TC 001943.

Ruegg, J.C.; Rudloff, A.; Vigny, C.; Madariaga, R.; de Chabalier, J.B.; Campos, J.; Kausel, E.; Barrientos, S.; Dimitrov, D. 2009. Interseismic strain accumulation measured by GPS in the seismic gap between Constitución and Concepción in Chile. Physics of the Earth and Planetary Interiors 175: 78-85. doi: 10.1016/j.pepi.2008.02.015.

Sieh, K.; Ward, S.N.; Natawidjaja, D.; Suwargadi, B.W. 1999. Crustal Deformation at the Sumatran Subduction Zone Revealed by Coral Rings. Geophysical Research Letters 26 (20): 3141-3144.

Thomson, S.N. 2002. Late Cenozoic geomorphic and tectonic evolution of the Patagonian Andes between latitudes $42^{\circ} \mathrm{S}$ and $46^{\circ} \mathrm{S}$ : An appraisal based on fission-track results from the transpressional intra-arc Liquiñe-Ofqui fault zone. Bulletin of the Geological Society of America 114 (9): 1159-1173.

Tikoff, B. 1998. Sunda style tectonics and magmatic arc processes. Eos Transactions American Geophysical Union 79 (45): F222.

Tikoff, B.; Teyssier, C. 1994. Strain modeling of displacement-field partitioning in transpressional orogens. Journal of Structural Geology 16 (11): 1575 1588.

Wang, K.; Hu, Y.; Bevis, M.; Kendrick, E.; Smalley Jr., R.; Vargas, R.B.; Lauría, E. 2007. Crustal motion in the zone of the 1960 Chile earthquake: Detangling earthquake-cycle deformation and forearcsliver translation. Geochemistry, Geophysics, Geosystems 8: Q10010. doi: 10.1029/2007GC 001721 .

Manuscript received: November 15, 2016; revised/accepted: December 20, 2016; available online: Decemberr 20, 2016. 